\title{
Article
}

\section{The Impact of Financial Development and FDI on Renewable Energy in the UAE: A Path towards Sustainable Development}

\author{
Ahmed Samour*, M. Mine Baskaya and Turgut Tursoy (D) \\ Banking and Finance Department, Near East University, TRNC, 10 Mersin, Lefkosa 99040, Turkey; \\ minebaskaya@yahoo.com (M.M.B.); turgut.tursoy@neu.edu.tr (T.T.) \\ * Correspondence: ahmad.samour@neu.edu.tr
}

check for updates

Citation: Samour, A.; Baskaya, M.M.; Tursoy, T. The Impact of Financial Development and FDI on Renewable Energy in the UAE: A Path towards Sustainable Development. Sustainability 2022, 14, 1208. https:// doi.org/10.3390/su14031208

Academic Editor: Donato Morea

Received: 22 December 2021

Accepted: 15 January 2022

Published: 21 January 2022

Publisher's Note: MDPI stays neutral with regard to jurisdictional claims in published maps and institutional affiliations.

Copyright: (C) 2022 by the authors. Licensee MDPI, Basel, Switzerland. This article is an open access article distributed under the terms and conditions of the Creative Commons Attribution (CC BY) license (https:// creativecommons.org/licenses/by/ $4.0 /)$.

\begin{abstract}
Several empirical studies have explored the influence of financial development on energy consumption; however, the impact of financial development, economic growth, and FDI on renewable energy consumption $(R E C)$ has not been studied in the case of the UAE. For this purpose, the long and short-run interactions among economic growth, FDI, financial development, and renewable energy consumption are explored by applying the new technique of bootstrap autoregressive distributed lag, along with Granger causality analysis, in the context of the UAE for the period from 1989-2019. Using estimation techniques, the study reveals the main findings and implications for policymakers in the UAE. The present research provides significant empirical evidence that financial development, FDI, and economic growth can significantly increase renewable energy consumption in the UAE. Therefore, it is essential to promote financial development in the UAE in order to avert the financial risks that undermine the stability of the financial markets and that negatively affect the REC. Furthermore, policymakers in the UAE should promote the concept of green finance and should provide more funds for investments in green energy for sustainable energy development in the UAE.
\end{abstract}

Keywords: financial development; UAE; bootstrap ARDL; renewable energy; FDI

\section{Introduction}

The significant mitigation of environmental degradation that is necessary in order to stabilize the global climate at safe levels calls for effective international environmental agreements. The most prominent global environmental agreements are the Kyoto Protocol (1997) and the Paris agreement (2015). These agreements strongly recommend energy efficiency improvements and green energy sources as optimal solutions to reduce the amount of carbon dioxide [1]. By complying with global environmental agreements, several developed and developing countries have considered sources of renewable energy as alternative green energy sources. Renewable energy sources stem from natural resources, such as sunlight, rain, geothermal heat, and waves and they are considered to be clean energy sources that can decrease the harmful environmental effects [2]. Moreover, these sources are sustainable for present and future economic needs. Carbon emissions have quadrupled since 1950 and currently contribute to around $80 \%$ of greenhouse gas emissions. As a result of this change, the global climate faces several variations, or oscillations, in the world precipitation trends, as well as a reduction in the polar ice caps [3]. With the impacts of global climate changes becoming steadily more severe, governments are trying to reduce the levels of carbon emissions and create sustainable environments in their countries [4].

In the United Arab Emirates (UAE), world climate and green energy issues are prominent factors in the strategic plans for achieving sustainable development. In this context, the UAE has launched various economic and financial plans, affirming its commitment to the achievement of sustainable development, such as the green growth vision for 2071, and the energy strategy for 2050. In this line, the UAE aims to become climate neutral by 2050 [5]. The prime objective of this paper is to test the effect of financial sector development, FDI, and real income on the level of renewable energy consumption (REC) in the UAE. 
The UAE is located in the southeast of the Arabian Gulf, and it has a desert climate, where the sun almost always shines. It is no surprise that solar energy in the UAE is one of the promising renewable energy resources, with an average of ten hours of sunlight per day. The UAE has the potential to significantly take advantage of this abundant renewable energy. These sources significantly sustain the electricity sector needs in the UAE. Because renewable energy sources are becoming a trend as alternative sources to traditional energy sources, it has become essential to design a green energy strategy, as it is inherently linked to financial development, which determines the power of an economy [5].

The banking sector in the UAE experienced positive developments from 1989 to 2019. In this context, the value of the local credit from the banks to the private sector as a share of the GDP in 2019 was roughly seven times higher than the value in 1989. It rose to $74 \%$ in 2019, compared to 30\% in 1989 (see Figure 1). However, the development of the banking system is an essential issue for the UAE, which aims to double the size of its economy over the next decade. Environmental degradation negatively affects the promotion of inclusive and sustainable economic growth in this country. Therefore, policymakers need to devote more attention to the consequences of economic policies on $\mathrm{CO}_{2}$ emissions and renewable energy. One of the main significant factors in renewable energy consumption is financial sector development. In essence, the financial sector makes decisions about who to lend to and in what to invest. Therefore, their choices affect business practices and investment [6]. Some types of renewable energy, such as solar energy projects, are considered an expensive investment. This type of investment requires a high initial cost and long-term loans. In this context, the financial sector helps the investors obtain the lending capital, which facilitates their expansion of the production scale, including the use of more equipment, thereby significantly increasing the energy levels [7]. Furthermore, the financial sector creates investment opportunities for the markets by increasing confidence for investors, which further lessens the capital cost and risk. Financial advancement widens the investment opportunities across the borders that facilitate the adoption of the latest technological energy-efficient products [8]. However, when the financial sector provides funds for the investors, this boosts the total factor productivity and the capital accumulations, thereby increasing the real income and the energy consumption [9]. By taking the influence of the financial sector on energy consumption into consideration, the current research can test the impact of financial sector policies on the consumption of renewable energy. In fact, the financial industry plays a crucial role in the attainment of economic and financial stability through the credit they provide to the markets and individuals. The financial sector should use this credit to support investment in renewable energy sources.

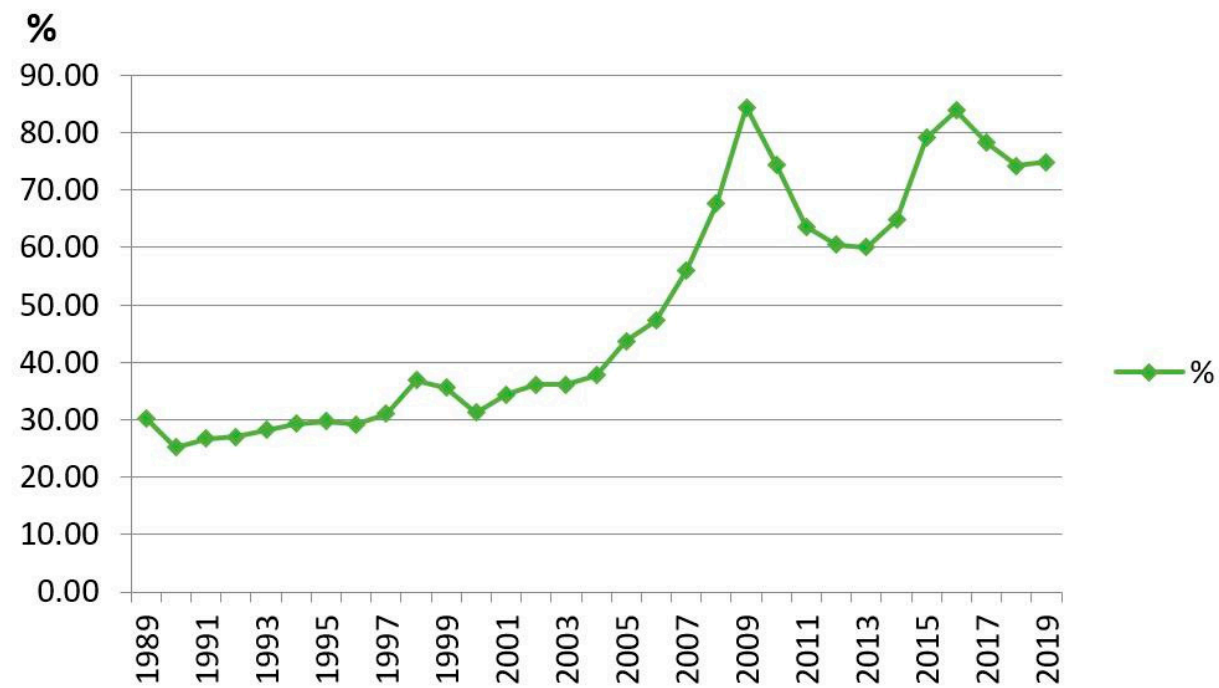

Figure 1. Domestic credit to the private sector by banks (\% of GDP), for the UAE. 
A large number of papers have focused on the energy consumption-economic growth link (see, e.g., [10-21]). However, in the existing empirical literature, there are a limited number of empirical studies that have tested the impact of financial development on renewable energy (see, e.g., [22-26]). The current paper aims to be the first to empirically study the literature by focusing on the role of financial development in green energy consumption in the UAE, using the novel technique of the bootstrap ARDL approach [27]. Therefore, the current research fills in the gaps in the existing literature in two different ways. First, to the best of our research knowledge, no empirical study has attempted to evaluate the effect of financial sector development on REC in the UAE. Second, our research explores the links among the tested variables, namely, FDI, financial development, economic growth, and renewable energy in the UAE, using a novel bootstrap ARDL model [27].

The research aims to provide novel empirical evidence by exploring the influence of financial development and FDI on the UAE's renewable energy consumption, using the updated technique of the bootstrap ARDL approach, as introduced by McNown et al. in 2018 [27]. The present research provides two main contributions to the existing empirical literature. First, to the best of our academic knowledge, no empirical paper has examined the effect of financial development on the UAE's renewable energy consumption. Second, the present research provides a robust analysis by exploring the tested variables using the updated technique of the bootstrap ARDL approach [27]. The present research aims to provide valuable conclusions and recommendations to help the UAE's policymakers to achieve sustainable and green economic growth through the diversification of its energy mix and through increasing investment in the use of clean energy sources.

The following sections of the current paper are as follows: Section 2 presents a review of the literature; Section 3 outlines the empirical model and the research methodology; Section 4 presents the empirical findings; and Section 5 presents the conclusions of our research.

\section{Review of Literature}

The reviewed literature is divided into three sections: (i) The linkage between real income and REC; (ii) The nexus between FDI and REC; and (iii) the FDI-REC linkage.

\subsection{Real Income and Renewable Energy Consumption}

Much research has considered the effects of real income on energy consumption. The empirical research on the connection between the consumption of energy and real income can be shown in four hypotheses: (i) The growth hypothesis (GH), which is accepted if there is a unidirectional causal connection between the consumption of energy and the real income [10]; (ii) The conservation hypothesis $(\mathrm{CH})$, which is accepted if there is a unidirectional causal connection between the real income and the consumption of energy [11]; (iii) The feedback hypothesis (FH), which is accepted if there is a bidirectional causal connection between the real income and the consumption of energy; and (iv) The neutrality hypothesis $(\mathrm{NH})$, which is accepted if there is no causal linkage between the real income and the consumption of energy [10]. The effects of the real income on the consumption of energy in recent years has drawn extensive attention. In this respect, the authors of [11] used the FMOLS model, and the findings show that a bidirectional association exists in 80 selected countries for the 1990-2007 period. Applying the ARDL model [12] showed that there is a positive interconnection between real income and NREC in the BRICS nations for the period from 1971-2010. The authors of [13] utilized the Granger causality model and explored the effects of the real income on NRC in the G7 countries for the 1960-2010 period. The outcomes confirm that the feedback hypothesis is valid in Japan; the conservation hypothesis holds in Italy; the growth hypothesis is relevant in Canada; and the neutrality hypothesis is relevant in France, the United States, and the United Kingdom. The authors of [28] suggest that economic complexity is a policy factor for overall energy transformation and renewable energy demand in India. 
The authors of [29] utilized the Granger causality test and discovered a significant linkage between real income and REC in Turkey for the period from 1970-2006, and the findings show the existence of the feedback hypothesis in Turkey. In contrast, the authors of [15] found that the GDP is not related to REC for the period from 1990-2015. The authors of [14] used the data period from 1980-2012, and proved that the GDP is positively related to the REC for 11 MENA countries. The authors of [17] used the data period from 1990-2013 and demonstrate that the GDP is positively related to the REC for 29 OECD counties. The authors of [16] used the annual data period from 1980-2014, and proved that the economic growth positively affected the REC for G7 countries. The authors of [18] evaluated the impact of economic growth on the REC for the period from 1980-2012. The findings prove that there is a significant positive interconnection between economic growth and the REC in 30 sub-Saharan African countries. Recently, the authors of [19] explored the influence of economic growth on the REC in Croatia over the period from 2004-2014. The authors of [30] affirm that economic growth has a significant impact on renewable energy consumption in G7 countries. The outcomes affirm that economic growth led to an increase in REC over the studied period. The authors of [20] affirm a significant causal interconnection between economic growth and the REC in 26 selected countries over the period from 1990-2018. The authors of [21] affirm a significant positive association between economic growth and REC in the United States.

\subsection{FDI and Renewable Energy Consumption}

The link between FDI and NREC has attracted significant attention in the literature over the last few years. For instance, the authors of [31] evaluated the influence of FDI on the levels of GDP and NREC in 20 different selected countries. The authors affirm that FDI plays a significant role in energy intensity deduction. The authors of [32] explored the interaction among FDI and NRE in China over the annual periods from 1982-2012. The results affirm that FDI positively affected the levels of NREC in China over the tested period. The authors of [33] tested the link between FDI and the demand for energy for 27 countries in Africa. The findings reveal that FDI had a powerful influence on the demand for energy in the selected countries. There are a limited number of studies that test the impact of FDI on green energy. For instance, the authors of [34] utilized the ARDL test and affirm that FDI significantly affected the green energy demand in the UAE. The authors of [35] report that there is a significant linkage between FDI and REC for 20 emerging market nations. The authors of [36] utilized the ARDL model and examined the impact of FDI on REC in Turkey, China, India, Russia, South Africa, and Brazil. The findings show that FDI negatively affected REC. Recently, the authors of [37] investigated the interaction between FDI and REC in China over the period from 2000 to 2015. The findings prove the positive and powerful influence of FDI on the levels of REC in China. The authors of [38] tested the linkage between FDI and REC in Kazakhstan and Uzbekistan over the period from 1992 to 2018. The findings confirm that FDI positively affected the levels of REC in Kazakhstan and Uzbekistan.

\subsection{Financial Development and the Consumption of Renewable Energy}

Many empirical studies, e.g., [39-41], have stated that the development of the financial sector, including the development of the banking performance, accelerates the economic growth rate. The authors of [39] demonstrate that the provision of more funds by the banks to the markets stimulates and promotes consumption, investment, economic growth, and the demand for energy. The authors of [40] show that positive economic growth and financial development has strong links to the rates of growth, capital accumulation, and economic efficiency, which, in turn, lead to an increase in the consumption of energy. However, many empirical papers have studied the interactions between financial development, nonrenewable energy consumption (NEC), and renewable energy consumption (REC). Some empirical studies reveal that financial development increases NREC; the authors of [42] reveal that financial development positively affected the demand for energy in 
Malaysia over the tested period, from 1971-2009. The authors of [43] found that the higher development of financial levels led to higher NREC in European countries for the period from 1990-2011. The authors of [44] used the VECM approach and confirm that financial development positively affected the NREC in India over the period from 1970-2012. The authors of [45] affirm that financial development positively affected the levels of NREC in 22 selected emerging countries over the period from 1990-2006. The authors of [46] used the period from 1984-2014, and they affirm that financial development had a powerful impact on the NREC for 79 countries. The authors of [47] used annual panel data from 1990-2011, and they found appositive links between financial development and NREC for 65 selected countries.

There are a limited number of studies on the linkage between financial development and REC. The authors of [48] show that financial development significantly contributed to the REC in 22 emerging countries over the period from 1990-2010. The authors of [49] used the annual data for 30 countries over the period from 2000-2013, and they found that financial development positively affected the levels of REC. The authors of [22] affirm that financial development contributed significantly to the levels of $R E C$ in Russia over the period from 1990-2021. The authors of [23] affirm that financial development had a positive influence on REC in China, India, Brazil, and South Africa from 1990-2012. The authors of [24] confirm a positive interaction between financial development and REC in China for the period from 1992 to 2013. Recently, the authors of [25] demonstrated that financial development led to increases in the shares of REC in 28 European countries, over the period from 1990-2021. The authors of [26] utilized nonlinear autoregressive distributed lags and reveal that financial development had a statistically significant influence on $R E C$ in the United States over the period from 1975-2019.

In summary, there are several empirical studies that have explored the influence of financial development on energy consumption using different estimate methods. These studies affirm the significant role of financial development in renewable energy. However, the influence of financial development on renewable energy consumption $(R E C)$ has not been studied in the case of the UAE. For this purpose, the long- and short-run interactions among economic growth, FDI, financial development, and renewable energy consumption are explored by applying the new technique of bootstrap autoregressive distributed lag, along with Granger causality analysis, in the context of the UAE for the period from 1989-2019. To the best of our knowledge, no empirical research has evaluated the impact of financial development on the UAE's renewable energy consumption.

\section{Research Methodology and Data Sources}

The present study aims to explore the impact of economic growth, FDI, and financial sector development on REC in the UAE. The tested model for economic growth, financial sector development, FDI, and REC in the UAE is formulated as follows:

$$
\ln R E C_{\mathrm{it}}=\beta_{0}+\gamma_{1} \ln E G_{\mathrm{it}}+\beta_{2} \ln F D I_{\mathrm{it}}+\beta_{3} \ln F D_{\mathrm{it}}+\varepsilon_{\mathrm{t}}
$$

In Equation (1), the REC is the percentage of the renewable energy consumption from the total nonrenewable energy consumption; the EG is the UAE's GDP $(2010=100)$ in USD; FD is the credits provided by the UAE banks to the private sector as a percentage of the GDP; and FDI is the foreign direct investment. All the tested series were converted into a natural log. The data of this research is the annual data covering the period from 1989-2019. The selected data of this paper are retrieved from the World Bank website.

\section{Unit Root and Cointegration Tests}

Traditional unit root tests do not include the structural break date (SBD); to overcome this problem, the present study uses the Zivot-Andrews (ZA, 2002) [50] and the ClementeMontañes-Reyes (CMR, 1998) [51] unit root tests, with one and two break dates. To investigate the connection between financial development, FDI, economic growth, and REC 
in the UAE, the present research utilizes the updated technique of ARDL, as suggested by McNown et al. (2018) [27].

In the traditional ARDL approach, an F-test (Fstatistic ${ }_{o v}$ ) on all the lagged level variables $\left(H_{0}: \gamma_{1}=\gamma_{2}=\gamma_{3}=\gamma_{4}=0\right)$, and a T-test on the lagged level dependent studied variable, $\left(H_{0}: \gamma_{1}=0\right)$, are used to capture the long relation among the examined variables. McNown et al. (2018) updated the ARDL testing model, and suggest an additional F-test $\left(H_{0}: \gamma_{2}=\gamma_{3}=\gamma_{4}=0\right)$ on the lagged level independent variables in the updated ARDL testing, which is complementary to the aforementioned (Fstatistic $c_{o v}$ ) and the (tstatistic ${ }_{D V}$ ) of Pesaran et al. (2001) [52]. Therefore, the bootstrap ARDL approach will be examined on the basis of all three tests: (i) An F-test $\left(F\right.$ statistic $_{o v}$ ) on the coefficients ofn the lagged levels of all the variables;: (ii) A $t$-test (tstatistic ${ }_{D V}$ ) on the coefficient of the lagged level of the dependent variable; and (iii) An F-test $\left(\right.$ statistic $\left._{I D V}\right)$ on the coefficient on the lagged level of the independent variable (Goh and McNown, 2020). According to McNown et al. (2018) [27] and Goh and McNown (2020) [53], these three tests should be applied to distinguish between cointegration, non-cointegration, and degenerate cases. There exist two degenerate cases, and both of them mean that the integration among the tested variables is not valid. The first degenerate case is observed when the lagged level dependent variable is insignificant, while the second degenerate case is observed when the lagged level independent variables are insignificant [27].

The bootstrap ARDL critical values (CVs) include the features of the combination integration of each time-series employing the ARDL bootstrap procedures. These steps lead to an overcoming of the instability issue in the findings of traditional cointegration tests, as well as to the provision of a better result than other tests of cointegration. In this sense, the CVs of the ARDL test allow for only one tested variable to be endogenous, whereas, in the updated ARDL test, the CVs allow for the endogeneity of selected explored variables. Moreover, this technique is advisable for time-series that include more than one examined tested variable [54-57]. The cointegration among economic growth, financial sector development, and FDI on REC in the UAE will be determined if the values of

$\left(\right.$ sstatistic $\left._{v v}\right),\left(\right.$ tstatistic $\left._{D V}\right)$, and $\left(\right.$ sstatistic $\left._{I D V}\right)$ are higher than those of the CV bootstrap technique [54].

The equation of ARDL testing is formulated and presented as follows:

$$
\begin{aligned}
\Delta \ln R E C_{\mathrm{t}}=\alpha_{0} & +\sum_{\mathrm{i}=1}^{\mathrm{m}} \beta_{1} \Delta \ln R E C_{\mathrm{t}-\mathrm{j}}+\sum_{\mathrm{i}=1}^{\mathrm{m}} \beta_{2} \Delta \ln E G_{\mathrm{t}-\mathrm{j}}+\sum_{\mathrm{i}=1}^{\mathrm{m}} \beta_{3} \Delta \ln F D I_{\mathrm{t}-\mathrm{j}} \\
& +\sum_{\mathrm{i}=1}^{\mathrm{m}} \beta_{4} \Delta \ln F D_{\mathrm{t}-\mathrm{j}}+\gamma_{1} \ln R E C_{\mathrm{t}-1}+\gamma_{2} \ln E G_{\mathrm{t}-1}+\gamma_{3} \ln F D I_{\mathrm{t}-1} \\
& +\gamma_{4} \ln F D_{\mathrm{t}-1}++\gamma_{5} \varnothing D 1_{\mathrm{t}}+\omega E C T_{\mathrm{t}-1}+\varepsilon_{1 \mathrm{t}}
\end{aligned}
$$

where $\varepsilon_{1 \mathrm{t}}$ symbolizes the error term; $\Delta$ is the operator of the first difference; $\alpha$ is the constant term; $\beta_{1}, \beta_{2}, \beta_{3}, \beta_{4}$ refer to the short-term coefficients of the tested variables; $\gamma_{1}, \gamma_{2}, \gamma_{3}, \gamma_{4}, \gamma_{5}$ refer to the long-term coefficients of the tested variables; $\ln R E C_{\mathrm{t}}, \ln E G_{\mathrm{t}}$, $\ln F D I_{\mathrm{t}}, \ln F D_{\mathrm{t}}$ represent the selected variables of the study; $\mathrm{m}$ symbolizes the optimal of the lags; and $\omega \mathrm{ECT}_{\mathrm{t}-1}$ is the error correction term that reflects the adjustment velocity between the studied variable. $\varnothing \mathrm{D} 1_{\mathrm{t}}$ represents the dummy variable that indicates structural changes. The dummy variable is added to Equation (2) in order to capture the economic shocks, namely, the 2001 Turkish crisis. During the 2001 crisis, there were significant decreases in the renewable energy consumption, FDI, and the GDP.

To confirm that the tested model of the present study is correct and is well specified, the study uses five diagnostic tests, namely, the Breush-Pagan-Godfrey heteroscedasticity test $\left(X^{-B G H}\right)$; the Breush-Pagan-Godfrey heteroscedasticity test $\left(X^{-B P G H}\right)$; the Ramsey $\operatorname{RESET}$ test $\left(\mathrm{X}^{-R R}\right)$; the normality test $\left(X^{-n D}\right)$; and the ARCH test $\left(X^{-A R C H}\right)$. Moreover, the study used the CUSUM and CUSUM square tests to confirm that the tested model was stable and correct. Furthermore, the Granger causality method was utilized to explore the causal interaction amongst the investigated variables. In this test, $\left(E C^{\text {Term }}\right)$ defines the 
short-term level variations of the variables studied from the long-term equilibrium level. The ECM formulated in Equations (3)-(6) are as follows:

$$
\begin{aligned}
\Delta \ln R E C_{\mathrm{t}}=\alpha_{0} & +\sum_{\mathrm{i}=1}^{\mathrm{p}} \beta_{1} \Delta \ln R E C_{\mathrm{t}-\mathrm{j}}+\sum_{\mathrm{i}=1}^{\mathrm{q}} \beta_{2} \Delta \ln E G_{\mathrm{t}-\mathrm{j}}+\sum_{\mathrm{i}=1}^{\mathrm{q}} \beta_{3} \Delta \ln F D I_{\mathrm{t}-\mathrm{j}} \\
& +\sum_{\mathrm{i}=1}^{\mathrm{q}} \beta_{4} \Delta \ln F D_{\mathrm{t}-\mathrm{j}}+\omega E C \mathrm{~T}_{\mathrm{t}-1}+\varepsilon_{1 \mathrm{t}} \\
\Delta \ln E G_{\mathrm{t}}=\alpha_{0} \quad & +\sum_{\mathrm{i}=1}^{\mathrm{p}} \beta_{1} \Delta \ln E G_{\mathrm{t}-\mathrm{j}}+\sum_{\mathrm{i}=1}^{\mathrm{q}} \beta_{2} \Delta \ln R E C_{\mathrm{t}-\mathrm{j}}+\sum_{\mathrm{i}=1}^{\mathrm{q}} \beta_{3} \Delta \ln F D I_{\mathrm{t}-\mathrm{j}} \\
& +\sum_{\mathrm{i}=1}^{\mathrm{q}} \beta_{4} \Delta \ln F D_{\mathrm{t}-\mathrm{j}}+\omega E C \mathrm{~T}_{\mathrm{t}-1}+\varepsilon_{1 \mathrm{t}} \\
& +\sum_{\mathrm{i}=1}^{\mathrm{p}} \beta_{1} \Delta \ln F D I_{\mathrm{t}-\mathrm{j}}+\sum_{\mathrm{i}=1}^{\mathrm{q}} \beta_{2} \Delta \ln R E C_{\mathrm{t}-\mathrm{j}}+\sum_{\mathrm{i}=1}^{\mathrm{n}} \beta_{3} \Delta \ln E G_{\mathrm{t}-\mathrm{j}} \\
& +\sum_{\mathrm{i}=1}^{\mathrm{q}} \beta_{4} \Delta \ln F D_{\mathrm{t}-\mathrm{j}}+\omega E C \mathrm{~T}_{\mathrm{t}-1}+\varepsilon_{1 \mathrm{t}} \\
& +\sum_{\mathrm{i}=1}^{\mathrm{p}} \beta_{1} \Delta \ln F D_{\mathrm{t}-\mathrm{j}}+\sum_{\mathrm{i}=1}^{\mathrm{q}} \beta_{2} \Delta \ln R E C_{\mathrm{t}-\mathrm{j}}+\sum_{\mathrm{i}=1}^{\mathrm{q}} \beta_{3} \Delta \ln E G_{\mathrm{t}-\mathrm{j}} \\
& +\sum_{\mathrm{i}=1}^{\mathrm{q}} \beta_{4} \Delta \ln F D I_{\mathrm{t}-\mathrm{j}}+\omega E C T_{\mathrm{t}-1}+\varepsilon_{1 \mathrm{t}}
\end{aligned}
$$

where $\Delta$ symbolizes the operator of the first difference; $\varepsilon_{1 \mathrm{t}}$ symbolizes the error term; and $\omega \mathrm{ECT}_{\mathrm{t}-1}$ is the lagged ECT. The causal linkage between the tested variables in the short-run level is tested applying the Wald test's (F)statistics [58]. Figure 2 shows the methodology structure of this research.

\section{Methodology Structure}
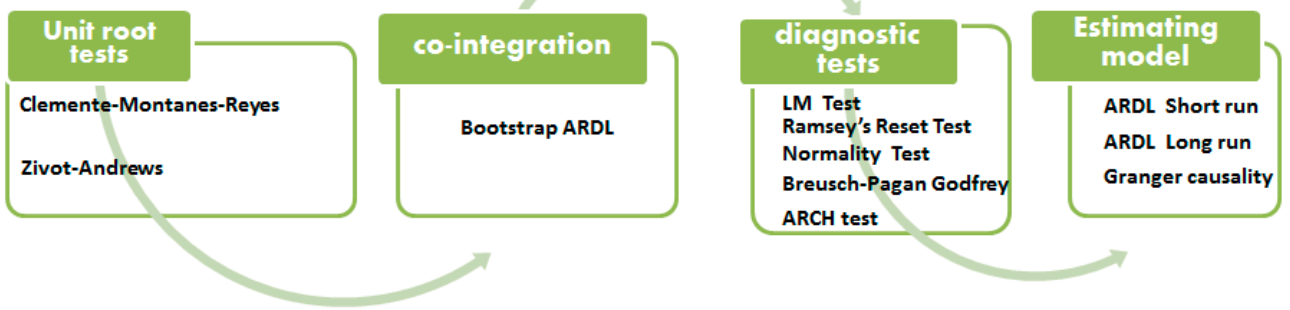

Figure 2. Structure of the methodology.

\section{Results and Discussion}

In Tables 1 and 2, the outcomes show that the REC, EG, FDI, and FD variables are stationary and integrated at the first difference $(\Delta)$. Hence, the selected variables have a (1) order of integration level. Therefore, Equation (1) of this study is passable as the studied model of cointegration. The outcomes of the B-ARDL testing of the cointegration approach are given in Table 3 . The outcomes prove that the $F_{\text {Pesaran }}, t_{\text {dependent }}$, and $F_{\text {independent }}$ values exceed the B-ARDL CVs. These results affirm that the cointegration among the REC, EG, $F D I$, and FD is valid. The linkages among the variables is presented in Figure 3.

Table 4 displays the empirical outcomes of the short- and long-run analyses from the ARDL testing model. The findings report that the economic growth is positive and significantly linked to the REC at a $1 \%$ level of significance in the long run. A $1 \%$ increase in the economic growth in the UAE is accompanied by a $0.280 \%$ improvement in the REC. These findings are similar to those of the authors of [19-21,59], who affirmed a significant positive association between economic growth and REC. 
Table 1. The ZA unit root test results.

\begin{tabular}{cccccc}
\hline & \multicolumn{2}{c}{ Level } & \multicolumn{3}{c}{ First Differences } \\
\hline Tested Variable & $\mathbf{t}-{ }^{S T A T}$ & SBD $^{1}$ & Variables & $\mathbf{t}-{ }^{\text {STAT }}$ & SBD $^{1}$ \\
\hline $\ln R E C_{\mathrm{t}}$ & -1.250 & 1990 & $\ln R E C_{\mathrm{t}}$ & $-6.410^{* *}$ & 2001 \\
$\ln E G_{\mathrm{t}}$ & -1.466 & 2010 & $\ln E G_{\mathrm{t}}$ & $-5.991^{* *}$ & 2001 \\
$\ln F D I_{\mathrm{t}}$ & -2.679 & 1994 & $\ln F D I_{\mathrm{t}}$ & $-6.401^{* *}$ & 2006 \\
$\ln F D_{\mathrm{t}}$ & -1.2510 & 1996 & $\ln F D_{\mathrm{t}}$ & $-6.001^{* *}$ & 2019 \\
\hline
\end{tabular}

** indicates the significances of the variables at the $5 \%$ level. SBD ${ }^{1}$ means one structural break date.

Table 2. The CMR unit root test results.

\begin{tabular}{cccccccc}
\hline & \multicolumn{3}{c}{ Level } & & \multicolumn{3}{c}{ First Differences } \\
\hline Tested Variable & $\mathbf{t}-{ }^{\text {STAT }}$ & SBD $^{1}$ & SBD $^{2}$ & Variables & t- STAT & SBD $^{1}$ & SBD $^{2}$ \\
\hline $\ln R E C_{\mathrm{t}}$ & -2.001 & 1997 & 2004 & $\Delta \ln R E C_{\mathrm{t}}$ & $-6.310^{* *}$ & 2001 & 2011 \\
$\ln E G_{\mathrm{t}}$ & -1.345 & 1999 & 1996 & $\Delta \ln E G_{\mathrm{t}}$ & $-7.661^{* *}$ & 1994 & 2018 \\
$\ln F I_{\mathrm{t}}$ & -1.441 & 2001 & 2012 & $\Delta \ln F D I_{\mathrm{t}}$ & $-8.010^{* *}$ & 1998 & 2011 \\
$\ln F D_{\mathrm{t}}$ & -2.661 & 2014 & 2016 & $\Delta \ln F D_{\mathrm{t}}$ & $-8.331^{* *}$ & 2011 & 2018 \\
\hline
\end{tabular}

** indicates the significances of the variables at $5 \% . \mathrm{SBD}^{1}$ and $\mathrm{SBD}^{2}$ mean one and two structural break dates respectively.

Table 3. The bootstrap ARDL cointegration analysis.

\begin{tabular}{|c|c|c|c|c|c|c|c|c|c|}
\hline \multirow[b]{2}{*}{$\operatorname{ARDL}(0,1,1,0)$} & \multicolumn{4}{|c|}{ Bootstrap ARDL Results } & \multicolumn{5}{|c|}{ Diagnostic Tests Results } \\
\hline & Break Date & Fstatistic $_{o v}$ & tstatistic $_{D V}$ & Fstatistic $I D V$ & $x^{-B G H}$ & $x^{-B P G H}$ & $x^{-R R}$ & $x^{-N D}$ & $x^{-A R C H}$ \\
\hline $\begin{array}{c}(R E C, E G, F D I, \\
\text { and } F D)\end{array}$ & 2001 & $6.85^{* *}$ & $-4.95^{* *}$ & $5.88^{* *}$ & $0.22^{F S}$ & $1.81^{F S}$ & $1.98^{F S}$ & $0.95^{F S}$ & $1.85^{F S}$ \\
\hline Bootstrap-based table CV 5\% & & 2.9 & -3.39 & 4.41 & $0.55^{P V}$ & $0.61^{P V}$ & $0.75^{P V}$ & $0.56^{P V}$ & $0.74^{P V}$ \\
\hline
\end{tabular}

** is the statistical sign at $5 \% ; P V$ is the $p$-value; $F$ statistic $_{o v}$ is the F-test on all the lagged level variables; $t$ statistic ${ }_{D V}$ is the t-test on the lagged dependent variables; and $F$ statistic $_{I D V}$ is the F-test on the lagged independent variable. FS means F statistic.

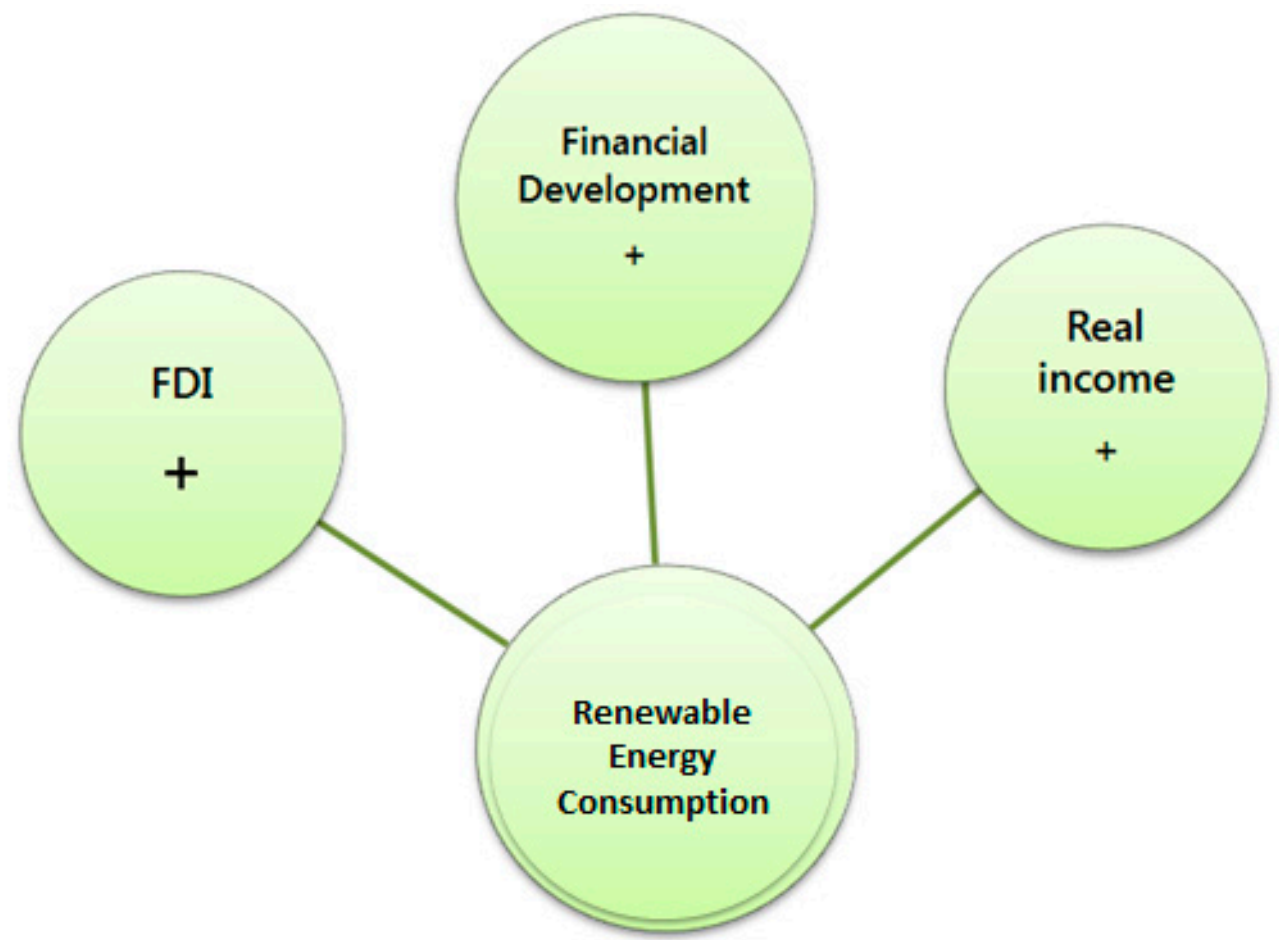

Figure 3. The linkages among the variables. Source: the authors' own preparation. 
Table 4. ARDL testing results.

\begin{tabular}{cccc}
\hline Variable & Coefficient & T-Statistic & $p$-Value \\
\hline$\Delta \ln E G_{\mathrm{t}}$ & $0.021^{* * *}$ & 0.163 & 0.551 \\
$\Delta \ln F D I_{\mathrm{t}}$ & $0.091^{* * *}$ & 0.651 & 0.00 \\
$\Delta \ln F D_{\mathrm{t}}$ & $0.031^{* * * *}$ & 0.451 & 0.00 \\
$\ln E G_{\mathrm{t}}$ & $0.280^{* * *}$ & 1.22 & 0.00 \\
$\ln F D I_{\mathrm{t}}$ & $0.009^{* *}$ & 0.179 & 0.01 \\
$\ln F D I_{\mathrm{t}}$ & $0.033^{* * *}$ & 0.441 & 0.00 \\
$\mathrm{D} 2001^{* * *}$ & -1.210 & 0.00 \\
$\mathrm{ECT} \mathrm{T}_{\mathrm{t}-1}$ & $-0.091^{* * *}$ and ${ }^{* * *}$ mean significances of the tested variables at 5 and $1 \%$, respectively. & 0.00 \\
\hline
\end{tabular}

Moreover, the findings affirm that $F D I$ is positive and significantly linked to the $R E C$ at a $5 \%$ level of significance. A $1 \%$ rise in FDI in the UAE is accompanied by a $0.009 \%$ improvement in the REC. This finding confirms that FDI has significantly affected $R E C$ in the UAE. These findings are similar to those of the authors of [36-38], who all report that FDI is positive and significantly linked to the $R E C$ in different selected countries and different econometric models.

Furthermore, the findings demonstrate that financial development increases $R E C$ positively and significantly in the short and long runs. The findings affirm that the financial development is positive and significantly linked to the REC at a $1 \%$ level of significance in the short and long runs. A $1 \%$ rise in financial development in the UAE is accompanied by a $0.03 \%$ improvement in the REC. These outcomes affirm that financial development has a powerful impact on the level of REC in the UAE. These outcomes are in agreement with [24,25].

$\mathrm{ECT}_{\mathrm{t}-1}$ implies that the production functions shift to a long-run equilibrium path, with a $15 \%$ adjustment of the speed from the short-run path to the long-run path.

To affirm the stability of the model of this study, we used five diagnostic tests, along with CUSUM and CUSUM square tests. The findings of the diagnostic tests are reported in Table 3. The findings of the Breush-Pagan-Godfrey heteroscedasticity test $\left(X^{-B G H}\right)$ and the Breush-Pagan-Godfrey heteroscedasticity $\left(X^{-B P G H}\right)$ affirm that the tested model is homoscedastic, and they affirm that there is no serial correlation in the explored model. Moreover, the normality test $\left(X^{-n D}\right)$ affirms that the tested is normally distributed, and the Ramsey RESET test $\left(X^{-R R}\right)$ affirms that the model is stable and correct. The CUSUM test and CUSUM square tests are presented in Figure 4. The figure shows that when the green line falls between the blue lines, the model is formulated correctly.

The present research utilizes the VECM to examine the causal linkage in both the short and long runs that can only be employed in the cointegrated tested series. The causal linkage among the studied variables helps us in crafting some appropriate suggestions for the promotion of green energy for sustainable energy development in the UAE. The outcome from Table 5 reports a causal link, from economic growth, financial sector development, and FDI, to the UAE's REC in the long run. Moreover, the outcomes from Table 5 display that there is a unidirectional causal link between economic growth and REC. This result confirms that the conservation hypothesis is valid in the UAE; this hypothesis implies the existence of a unidirectional link between $R E C$ and economic growth. Thus, the increase in economic growth led to the increase in the level of REC. These findings confirm that the economic growth significantly affected the REC in the UAE. Moreover, the findings report that there is a unidirectional causal connection, from FDI to REC. This finding confirms that FDI significantly affected the REC in the UAE. Finally, the results report that there is a unidirectional causal link, from financial development to $R E C$, in the UAE.

In addition, the outcomes show that there is a unidirectional causal link from $F D I$ and financial development to economic growth. This result confirms that FDI and financial development affects REC in the UAE through the economic growth factor. However, this result ensures that financial development can have a significant impact on sustainable energy development through the credit provided to banks and markets. Therefore, the 
present research suggests that policymakers in the UAE should use financial development to promote investment in green energy. The results of this research are essential for the UAE in terms of diversifying the energy formula by adding more green energy sources.
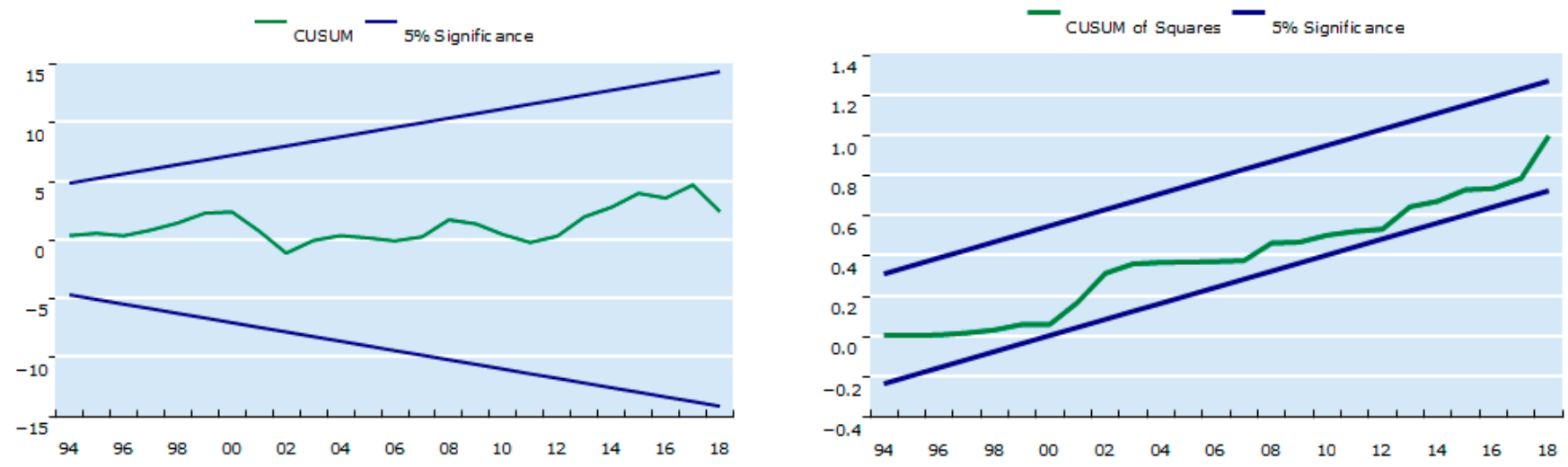

Figure 4. CUSUM and CUSUM square tests.

Table 5. Results of the Granger causality testing approach.

\begin{tabular}{cccccc}
\hline & $\Delta \ln R E C_{\mathbf{t}}$ & $\Delta \ln E G_{\mathbf{t}}$ & $\Delta \ln F D I_{\mathbf{t}}$ & $\Delta \ln F D_{\mathbf{t}}$ & $\mathbf{E C T}_{\mathbf{t}-\mathbf{1}}$ \\
\hline$\Delta \ln R E C_{\mathrm{t}}$ & - & $7.961^{* *}$ & $7.447^{* *}$ & $8.6794^{* *}$ & $-0.711^{* *}$ \\
$\Delta \ln E G_{\mathrm{t}}$ & 1.310 & - & $6.934^{*}$ & $6.346^{*}$ & -0.441 \\
$\Delta \ln F D I_{\mathrm{t}}$ & 0.909 & 1.374 & 2.114 & $7.661^{* *}$ & -0.322 \\
$\Delta \ln F D_{\mathrm{t}}$ & 0.826 & 1.115 & 1.554 & - & -0.114 \\
\hline
\end{tabular}

Note: ${ }^{*}$ and ${ }^{* *}$ denote significances at the 5 and $10 \%$ levels.

Finally, the findings show that the 2001 Turkish economic crisis had a significant impact on the levels of renewable energy. This result can be explained by the fact that renewable energy consumption decreased in 2001, which was linked with the decline in the GDP and FDI.

\section{Conclusions and Policy Implications}

Over the last few decades, the influence of energy consumption on the environment quality has increased significantly. Developed and developing countries have focused on sustainability efforts to decrease the levels of carbon emissions, and more attention is required to achieve this objective. In this context, sustainable energy development has become highly important because of increasing $\mathrm{CO}_{2}$ emissions. The UAE government has recognized the need to use green energy sources to address climate change and environmental sustainability through the diversification of their energy resources.

Several empirical studies have evaluated the interaction between energy consumption and financial development. However, the effects of financial development, along with the economic growth and the FDI, on renewable energy consumption (REC) has not been studied in the case of the UAE. For this purpose, the long- and short-run interactions between economic growth, FDI, financial development and REC was explored by applying the novel technique of bootstrap ARDL, along with the Granger causality test, in the context of the UAE for the period from 1989-2020. The limited selected data from 1989 to 2020 can be attributed to the fact that some data from before 1989 are not available. The new version of the ARDL test, as suggested by [27], is desired over traditional cointegration tests because of its ability to predict when resolving power and size limitation issues, and because of its corresponding features.

The findings from the ARDL test show that the real income positively and significantly affected the REC in the UAE in the long run. In addition, the findings show that FDI and financial development positively and significantly affected the REC in the UAE in both the short run and the long run, over the tested period. On the other hand, the findings 
from the Granger causality test affirm a causal link between real income, FDI, financial development, and REC. The empirical results of this study can be explained by several factors: (I) FDI and financial development affect the consumption of energy through their significant impact on real income; (II) FDI introduces new advanced technologies to the market, which require more energy use. However, FDI, income, and financial development affected change in the economic structure by providing more internal and external capital to the markets, which, in turn, led to an increase in the levels of energy; (III) The financial sector provides credit for the markets and individuals. Hence, this funding leads to the promotion of capital accumulation and boosts the total factor productivity. Subsequently, this leads to an increase in the real income and the REC.

The economy of the UAE is the fourth largest of the Middle Eastern countries, with a GDP of USD 414 billion in 2018. The banking sector in the UAE experienced positive developments over the period from 1989 to 2019 . The UAE has the potential to significantly take advantage of abundant renewable energy. These sources significantly sustain the electricity sector needs in the UAE. Because renewable energy sources are becoming a trend as alternative sources to the traditional energy sources, it has become important to design a green energy strategy, as it is inherently linked to financial development, which determines the power of an economy. In this sense, the UAE has taken some significant steps in establishing the renewable energy sector by diversifying its energy needs to address environmental quality. In this line, the UAE aims to become climate neutral by 2050 . On the basis of the findings of the present research, the study draws the following implications for policymakers in the UAE: First, the present research provides significant empirical evidence that financial development, FDI, and economic growth can help increase REC in the UAE. In this context, it is important to promote financial development in the UAE to avert the risks that undermine the stability of financial markets and adversely affect green energy. Furthermore, policymakers in the UAE should promote the concept of green finance and should provide more funds to investments in renewable energy. Second, the positive connection among financial development and green energy should encourage policymakers in the UAE to formulate strategies to promote green investments, such as, for instance, taxation deductions on green energy investments.

Finally, it is also important to promote energy efficiency by paying more attention to FDI requirements and policies. In this context, FDI policies should take into account energy saving and energy efficiency in the UAE. Moreover, the policymakers must be aware and must have a positive perception of the consumer and the investor to increase energy efficiency. In order to take advantage of green energy, policymakers in the UAE should make important investments in green energy resources, and they should scale down energy dependency on nongreen resources. However, the main and most significant implication of the present research for the policymakers in the UAE is the suggestion that they should design new strategies to promote green energy consumption by adding more green energy sources into the energy mix. These strategies may not only promote and sustain the energy sector in the UAE but may also limit its dependency on foreign suppliers of energy. Furthermore, the UAE's policymakers should design new green policies to limit the negative impact of nonrenewable energy consumption, using financial incentives, such as taxation deductions on green energy investments. The outcomes of this paper provide significant conclusions and recommendations for the UAE, heading it towards sustainable and green economic growth through the diversification of its energy formula, and shifting it towards more investment in, and consumption of, renewable energy sources. However, using more green energy sources would positively affect sustainability by providing several economic benefits; the diversification of the energy supply enhances economic development and creates more investment opportunities for the markets. Future empirical studies should be devoted to the investigation of the long-term linkages between different sectors of the economy and renewable energy consumption using different panel methods. 
Author Contributions: Methodology, A.S.; Software, A.S.; Writing—original draft, A.S.; Writing—review \& editing, A.S., M.M.B. and T.T. All authors have read and agreed to the published version of the manuscript.

Funding: This research received no external funding.

Institutional Review Board Statement: Not applicable.

Informed Consent Statement: Not applicable.

Data Availability Statement: Not applicable.

Conflicts of Interest: The authors declare no conflict of interest.

\section{References}

1. Abumunshar, M.; Aga, M.; Samour, A. Oil Price, Energy Consumption, and $\mathrm{CO}_{2}$ Emissions in Turkey. New Evidence from a Bootstrap ARDL Test. Energies 2020, 13, 5588. [CrossRef]

2. Shahzad, U.; Hussain, M.; Qin, F.; Amir, M. Reinvestigating the Role of Coal Consumption in Indian Economy: An ARDL and Causality Analysis. Eur. Online J. Nat. Soc. Sci. 2018, 7, 348.

3. Chishti, M.Z.; Ahmad, M.; Rehman, A.; Khan, M.K. Mitigations pathways towards sustainable development: Assessing the influence of fiscal and monetary policies on carbon emissions in BRICS economies. J. Clean. Prod. 2021, 292, 126035. [CrossRef]

4. Koondhar, M.A.; Shahbaz, M.; Ozturk, I.; Randhawa, A.A.; Kong, R. Revisiting the relationship between carbon emission, renewable energy consumption, forestry, and agricultural financial development for China. Environ. Sci. Pollut. Res. 2021, 28, 45459-45473. [CrossRef]

5. Al Naqbi, S.; Tsai, I.; Mezher, T. Market design for successful implementation of UAE 2050 energy strategy. Renew. Sustain. Energy Rev. 2019, 116, 109429. [CrossRef]

6. Altarhouni, A.; Danju, D.; Samour, A. Insurance Market Development, Energy Consumption, and Turkey's $\mathrm{CO}_{2}$ Emissions. New Perspectives from a Bootstrap ARDL Test. Energies 2021, 14, 7830. [CrossRef]

7. Jiang, C.; Ma, X. The Impact of Financial Development on Carbon Emissions: A Global Perspective. Sustainability $2019,11,5241$. [CrossRef]

8. Godil, D.I.; Sharif, A.; Ali, M.I.; Ozturk, I.; Usman, R. The role of financial development, R\&D expenditure, globalization and institutional quality in energy consumption in India: New evidence from the QARDL approach. J. Environ. Manag. 2021, 285, 112208.

9. Fatima, T.; Mentel, G.; Doğan, B.; Hashim, Z.; Shahzad, U. Investigating the role of export product diversification for renewable, and non-renewable energy consumption in GCC (gulf cooperation council) countries: Does the Kuznets hypothesis exist? Environ. Dev. Sustain. 2021, 9, 1-21. [CrossRef]

10. Ozturk, I.; Aslan, A.; Kalyoncu, H. Energy consumption and economic growth relationship: Evidence from panel data for low and middle income countries. Energy Policy 2010, 38, 4422-4428. [CrossRef]

11. Apergis, N.; Payne, J.E. Renewable and non-renewable electricity consumption-growth nexus: Evidence from emerging market economies. Appl. Energy 2011, 88, 5226-5230. [CrossRef]

12. Sebri, M.; Ben-Salha, O. On the causal dynamics between economic growth, renewable energy consumption, $\mathrm{CO}_{2}$ emissions and trade openness: Fresh evidence from BRICS countries. Renew. Sustain. Energy Rev. 2014, 39, 14-23. [CrossRef]

13. Ajmi, A.N.; Hammoudeh, S.; Nguyen, D.K.; Sato, J.R. On the relationships between CO 2 emissions, energy consumption and income: The importance of time variation. Energy Econ. 2015, 49, 629-638. [CrossRef]

14. Kahia, M.; Ben Aïssa, M.S.; Lanouar, C. Renewable and non-renewable energy use-economic growth nexus: The case of MENA Net Oil Importing Countries. Renew. Sustain. Energy Rev. 2017, 71, 127-140. [CrossRef]

15. Bulut, U.; Inglesi-Lotz, R. Which type of energy drove industrial growth in the US from 2000 to 2018? Energy Rep. 2019, 5, 425-430. [CrossRef]

16. Tugcu, C.T.; Topcu, M. Total, renewable and non-renewable energy consumption and economic growth: Revisiting the issue with an asymmetric point of view. Energy 2018, 152, 64-74. [CrossRef]

17. Gozgor, G.; Lau, C.K.M.; Lu, Z. Energy consumption and economic growth: New evidence from the OECD countries. Energy 2018, 153, 27-34. [CrossRef]

18. Adams, S.; Klobodu, E.K.M.; Apio, A. Renewable and non-renewable energy, regime type and economic growth. Renew. Energy 2018, 125, 755-767. [CrossRef]

19. Zivkovic, A.; Fosic, I.; Starcevic, D.P. Employee Turnover Trends in Croatia. Econ. Soc. Dev. Book Proc. 2020, 16, 155-162.

20. Asiedu, B.A.; Hassan, A.A.; Bein, M.A. Renewable energy, non-renewable energy, and economic growth: Evidence from 26 European countries. Environ. Sci. Pollut. Res. 2021, 28, 11119-11128. [CrossRef]

21. Salari, M.; Kelly, I.; Doytch, N.; Javid, R.J. Economic Growth and Renewable and Non-Renewable Energy Consumption: Evidence from the U.S. States. Renew. Energy 2021, 178, 50-65. [CrossRef]

22. Freidin, M.; Burakov, D. Economic growth, electricity consumption and internet usage nexus: Evidence from a panel of commonwealth of independent states. Int. J. Energy Econ. Policy 2018, 8, 267. 
23. Kutn, A.M.; Paramati, S.R.; Ummalla, M.; Zakari, A. Financing renewable energy projects in major emerging market economies: Evidence in the perspective of sustainable economic development. Emerg. Mark. Financ. Trade 2018, 54, 1761-1777. [CrossRef]

24. Wang, J.; Zhang, S.; Zhang, Q. The relationship of renewable energy consumption to financial development and economic growth in China. Renew. Energy 2021, 170, 897-904. [CrossRef]

25. Anton, S.G.; Nucu, A.E.A. The effect of financial development on renewable energy consumption. A panel data approach. Renew. Energy 2020, 147, 330-338. [CrossRef]

26. Lahiani, A.; Mefteh-Wali, S.; Shahbaz, M.; Vo, X.V. Does financial development influence renewable energy consumption to achieve carbon neutrality in the USA? Energy Policy 2021, 158, 112524. [CrossRef]

27. McNown, R.; Sam, C.Y.; Goh, S.K. Bootstrapping the autoregressive distributed lag test for cointegration. Appl. Econ. 2018, 50, 1509-1521. [CrossRef]

28. Ikram, M.; Xia, W.; Fareed, Z.; Shahzad, U.; Rafique, M.Z. Exploring the nexus between economic complexity, economic growth and ecological footprint: Contextual evidences from Japan. Sustain. Energy Technol. Assess. 2021, 47, 101460. [CrossRef]

29. Erdal, G.; Erdal, H.; Esengün, K. The causality between energy consumption and economic growth in Turkey. Energy Policy 2008, 36, 3838-3842. [CrossRef]

30. Rafique, M.Z.; Doğan, B.; Husain, S.; Huang, S.; Shahzad, U. Role of economic complexity to induce renewable energy: Contextual evidence from G7 and E7 countries. Int. J. Green Energy 2021, 18, 745-754. [CrossRef]

31. Mielnik, O.; Goldemberg, J. Foreign direct investment and decoupling between energy and gross domestic product in developing countries. Energy Policy 2002, 30, 87-89. [CrossRef]

32. Salim, R.; Yao, Y.; Chen, G.; Zhang, L. Can foreign direct investment harness energy consumption in China? A time series investigation. Energy Econ. 2017, 66, 43-53. [CrossRef]

33. Adom, P.K.; Opoku, E.E.O.; Yan, I.K.-M. Energy demand-FDI nexus in Africa: Do FDIs induce dichotomous paths? Energy Econ. 2019, 81, 928-941. [CrossRef]

34. Sbia, R.; Shahbaz, M.; Hamdi, H. A contribution of foreign direct investment, clean energy, trade openness, carbon emissions and economic growth to energy demand in UAE. Econ. Model. 2014, 36, 191-197. [CrossRef]

35. Paramati, S.R.; Ummalla, M.; Apergis, N. The effect of foreign direct investment and stock market growth on clean energy use across a panel of emerging market economies. Energy Econ. 2016, 56, 29-41. [CrossRef]

36. Kilicarslan, Z. The Relationship between Foreign Direct Investment and Renewable Energy Production: Evidence from Brazil, Russia, India, China, South Africa and Turkey. Int. J. Energy Econ. Policy 2019, 9, 291-297. [CrossRef]

37. Fan, W.; Hao, Y. An empirical research on the relationship amongst renewable energy consumption, economic growth and foreign direct investment in China. Renew. Energy 2020, 146, 598-609. [CrossRef]

38. Grabara, J.; Tleppayev, A.; Dabylova, M.; Mihardjo, L.W.W.; Dacko-Pikiewicz, Z. Empirical Research on the Relationship Amongst Renewable Energy Consumption, Economic Growth and Foreign Direct Investment in Kazakhstan and Uzbekistan. Energies 2021, 14, 332. [CrossRef]

39. Song, C.-Q.; Chang, C.-P.; Gong, Q. Economic growth, corruption, and financial development: Global evidence. Econ. Model. 2021, 94, 822-830. [CrossRef]

40. Ekanayake, E.M.; Thaver, R. The Nexus between Financial Development and Economic Growth: Panel Data Evidence from Developing Countries. J. Risk Financial Manag. 2021, 14, 489. [CrossRef]

41. Cheng, C.-Y.; Chien, M.-S.; Lee, C.-C. ICT diffusion, financial development, and economic growth: An international cross-country analysis. Econ. Model. 2021, 94, 662-671. [CrossRef]

42. Islam, F.; Shahbaz, M.; Ahmed, A.U.; Alam, M. Financial development and energy consumption nexus in Malaysia: A multivariate time series analysis. Econ. Model. 2013, 30, 435-441. [CrossRef]

43. Çoban, S.; Topcu, M. The nexus between financial development and energy consumption in the EU: A dynamic panel data analysis. Energy Econ. 2013, 39, 81-88. [CrossRef]

44. Shahbaz, M.; Van Hoang, T.H.; Mahalik, M.K.; Roubaud, D. Energy consumption, financial development and economic growth in India: New evidence from a nonlinear and asymmetric analysis. Energy Econ. 2017, 63, 199-212. [CrossRef]

45. Sadorsky, P. The impact of financial development on energy consumption in emerging economies. Energy Policy 2010, 38, 2528-2535. [CrossRef]

46. Chiu, Y.-B.; Lee, C.-C. Effects of financial development on energy consumption: The role of country risks. Energy Econ. 2020, 90, 104833. [CrossRef]

47. Omri, A.; Kahouli, B. Causal relationships between energy consumption, foreign direct investment and economic growth: Fresh evidence from dynamic simultaneous-equations models. Energy Policy 2014, 67, 913-922. [CrossRef]

48. Wu, L.; Broadstock, D.C. Does economic, financial and institutional development matter for renewable energy consumption? Evidence from emerging economies. Int. J. Econ. Policy Emerg. Econ. 2015, 8, 20-39. [CrossRef]

49. Kim, J.; Park, K. Financial development and deployment of renewable energy technologies. Energy Econ. 2016, 59, 238-250. [CrossRef]

50. Zivot, E.; Andrews, D.W. Further evidence on the great crash, the oil-price shock, and the unit-root hypothesis. J. Bus. Econ. Stat. 2002, 20, 25-44. [CrossRef]

51. Clemente, J.; Montañés, A.; Reyes, M. Testing for a unit root in variables with a double change in the mean. Econ. Lett. 1998, 59, 175-182. [CrossRef] 
52. Pesaran, M.H.; Shin, Y.; Smith, R.J. Bounds testing approaches to the analysis of level relationships. J. Appl. Econom. 2001, 16, 289-326. [CrossRef]

53. Goh, S.K.; McNown, R.; Wong, K.N. Macroeconomic implications of population aging: Evidence from Japan. J. Asian Econ. 2020, 68, 101198. [CrossRef]

54. Alhodiry, A.; Rjoub, H.; Samour, A. Impact of oil prices, the U.S interest rates on Turkey's real estate market. New evidence from combined co-integration and bootstrap ARDL tests. PLoS ONE 2021, 16, e0242672. [CrossRef]

55. Moyo, D.; Samour, A.; Tursoy, T. The Nexus Between Taxation, Government Expenditure and Economic Growth in South Africa. A fresh evidence from combined cointegration test. Stud. Appl. Econ. 2021, 39. [CrossRef]

56. Hashmi, S.M.; Bhowmik, R.; Inglesi-Lotz, R.; Syed, Q.R. Investigating the Environmental Kuznets Curve hypothesis amidst geopolitical risk: Global evidence using bootstrap ARDL approach. Environ. Sci. Pollut. Res. 2021, 1-14. [CrossRef]

57. Bhowmik, R.; Syed, Q.R.; Apergis, N.; Alola, A.A.; Gai, Z. Applying a dynamic ARDL approach to the Environmental Phillips Curve (EPC) hypothesis amid monetary, fiscal, and trade policy uncertainty in the USA. Environ. Sci. Pollut. Res. 2021, 1-15. [CrossRef]

58. Syed, Q.R.; Bouri, E. Impact of economic policy uncertainty on $\mathrm{CO}_{2}$ emissions in the US: Evidence from bootstrap ARDL approach. J. Public Aff. 2021, e2595. [CrossRef]

59. Mahi, M.; Phoong, S.W.; Ismail, I.; Isa, C.R. Energy-finance-growth nexus in ASEAN-5 countries: An ARDL bounds test approach. Sustainability 2020, 12, 5. [CrossRef] 